\title{
Hybrids between cultivated and wild carrots in natural populations in Denmark
}

\author{
LS Magnussen ${ }^{1}$ and TP Hauser ${ }^{1,2}$ \\ ${ }^{1}$ Plant Research Department, Risø National Laboratory, Roskilde, Denmark and ${ }^{2}$ Faculty of Life Sciences, Department of Ecology, \\ University of Copenhagen, Frederiksberg, Denmark
}

\begin{abstract}
Many cultivated plant species are able to hybridize with related wild plants. However, it is not clear whether their hybrids are able to survive and reproduce outside managed fields, and if cultivar genes introgress into wild populations. In areas where wild carrots co-occur with carrot root-crops, pollen and seeds may flow from two different sources in the fields to the surrounding wild populations: from pure cultivar plants that occasionally flower, and from flowering 'bolters' that originate from hybridizations between wild ( $\delta$ ) and cultivated carrots ( $q$ ) in seed production fields in warmer regions of the world. To test whether hybrids are formed and survive in wild Danish populations, and whether prolonged hybridization has led to introgression of cultivar genes, we collected leaf material from adult individuals growing close to
\end{abstract}

carrot fields and analysed their genotypic composition by AFLP. Four hybrids were identified among the 71 plants analysed, and these were most likely $F_{2}$ or backcross individuals, sired by pollen from hybrid bolters. Wild populations close to fields were genetically somewhat more similar to cultivars than wild populations far from fields, suggesting that neutral or beneficial cultivar alleles can introgress into the wild gene pool. Despite generations of improvement and adaptation of cultivar carrots to highly managed field conditions, hybrids can thus sometimes survive in wild populations close to carrot fields, and their genes transfer to wild populations by introgression.

Heredity (2007) 99, 185-192; doi:10.1038/sj.hdy.6800982; published online 2 May 2007

Keywords: daucus carota; wild carrot; cultivated carrots; bolters; hybridization; introgression

\section{Introduction}

Many cultivated plants are able to hybridize with wild relatives somewhere in their cultivation range (Ellstrand, 2003). However, even if hybridization is possible, the resulting hybrids may not be able to survive and reproduce in the habitats of either parent. Mixing the parental genomes, especially by recombination in $\mathrm{F}_{2}$ and later generation hybrids, may break up local adaptations and intrinsic coadaptations of gene complexes (Lynch, 1991), an effect called outbreeding depression. In the case of hybridization between polyploid cultivars and diploid relatives, chromosomal imbalances may add to a low fitness of hybrids (Hauser et al., 1998a). However, hybrids between cultivated and wild plants may sometimes exhibit improved fitness relative to their parents (Ellstrand, 2003), due to inheritance of beneficial crop alleles (Campbell et al., 2006), heterosis (Hauser et al., 1998b), and novel combinations of genes and traits of the parents (Hauser et al., 1998a; Hooftman et al., 2005). Transgression of traits from the two parents is thought to be a major mechanism for creating evolutionary novelties in hybrids (Lexer et al., 2003).

Fitness of hybrids between cultivated and wild plants has become the focus of increased interest, due to the

Correspondence: Dr TP Hauser, Department of Ecology, Faculty of Life Sciences, University of Copenhagen, Rolighedsvej 21, DK-1958 Frederiksberg, Denmark.

E-mail: tpha@life.ku.dk

Received 22 March 2006; revised 23 March 2007; accepted 26 March 2007; published online 2 May 2007 possible impacts of agricultural plants, particularly genetically modified crops, on weedy and wild populations. If hybridization produces inviable seeds, and if hybrids fail to survive and reproduce, wild populations growing close to fields may become endangered by a high influx of pollen from a neighbouring related crop (Rhymer and Simberloff, 1996). Extinction of local wild populations may cause losses of biodiversity and genetic resources for future plant breeding of the cultivars (Ellstrand, 2003; Song et al., 2005).

Alternatively, if hybrids of first and later generations are able to survive and reproduce, genes may over time transfer, introgress, between cultivated and wild related populations, unless there is strong selection against the particular genes (Pylkov et al., 2000). Gene transfer from wild to cultivated plants has contributed to the evolution of several crop species (Harlan, 1982). Gene transfer in the opposite direction, into wild populations, may result in various evolutionary outcomes, such as 'assimilation' of the wild populations to become 'hybridized into a new taxon' (Hegde et al., 2006), deterioration of genetic resources (Song et al., 2005), evolution of weeds (Campbell et al., 2006), loss of biodiversity (Song et al., 2005), and emergence of invasive plant types (Ellstrand and Schierenbeck, 2000). How often these outcomes happen, and have happened, during domestication and cultivation of crops, is largely unknown, due to lack of research and detection power.

Cultivated carrots (Daucus carota ssp. sativus) are able to hybridize with wild carrots (D. carota ssp. carota) (Heywood, 1983; Small, 1984), which grow in most regions of the world where carrots are cultivated (for 
example, Umehara et al., 2005). It is well known that wild carrots may pollinate seed plants in seed production fields (Heywood, 1983; Small, 1984; D'Antuono, 1985; Hauser and Bjørn, 2001), and seed lots sometimes have to be discarded. What is less known is that hybrid seeds may be transported with the cultivar seed lots to root production fields, sometimes far away, and planted. For example, seed used in Denmark is produced in regions with a warmer climate, such as Southern Europe, California, Chile and Australia. From their wild southern fathers, the hybrids inherit a potential for flowering in their first year (annuality) (Lacey, 1988; Hauser and Bjørn, 2001), and they therefore often flower (bolt) in root-crop fields if not weeded away. From these plants, pollen and seeds may disperse into neighbouring wild populations.

In our study region at the Lammefjord, Denmark, socalled 'bolters' of hybrid origin are found in many commercial fields and may occasionally form semipersistent weedy populations that survive rotation as dormant seeds (Hauser and Bjørn, 2001). A similar route of hybridization, via seed production regions, has been described for cultivated beets (Beta vulgaris) (Arnaud et al., 2003; Van Dijk, 2004). Another possibility for hybridization and gene transfer between cultivated and wild plants is a direct transfer of pollen from cultivar plants into wild populations. Despite being bred to be biennial, cultivated carrots sometimes flower in root-crop fields, especially after a cold spring (Atherton et al., 1990). Carrot flowers are highly attractive to bees and other insects, which may fly up to $6 \mathrm{~km}$ to forage on carrots (Gary et al., 1977).

Although it is clear that hybridization is possible, it is still uncertain whether hybrids are able to survive and reproduce in the natural habitats of wild carrots, and if cultivar genes thereby will be able to flow into wild populations. During domestication, cultivated carrots have been selected for orange, sweet and palatable roots, and adapted to cultivation under highly managed conditions in agricultural fields. Wild carrots, in contrast, have white, tough roots with a strong, bitter taste and have probably been continuously selected for stressful conditions and competition from grasses and other neighbours (for more trait differences, see Small, 1978; Heywood, 1983; Wijnheijmer et al., 1989; Hauser and Bjørn, 2001). Despite their ease of hybridization, carrot hybrids may therefore be maladapted outside fields; in other words, 'ecologically incompetent'. Thus, Small (1984) argued that 'domesticated features are simply too inadaptive to wild existence for transferred genes to survive. Natural selection in the wild coupled with strong artificial selection in cultivation seem to effectively block gene exchange'. Our own results on wild Danish carrots are somewhat contradictory. Experimental $F_{1}$ hybrids between wild Danish and cultivated carrots survived and reproduced in grasslands in Denmark (Hauser, unpublished), but hybrids were more frost sensitive than wild carrots (Hauser, 2002).

In this study we searched for adult hybrids of cultivated and wild carrots in natural carrot populations close to carrot fields in Denmark. Existence of such hybrids would indicate that spontaneous pollination takes place and that hybrids are able to survive under natural conditions. We also tested whether the hybrids we found were most likely produced by pure cultivar plants or by 'bolters' of hybrid (cultivar $q \times$ wild $\hat{o}$ ) origin. We further asked whether wild populations close to cultivated fields were genetically more similar to cultivars as compared to wild populations geographically further away. This would indicate that prolonged hybridization has led to the introgression of cultivar genes into wild populations.

\section{Materials and methods}

\section{Plant materials}

For our study, we used material from carrot cultivars, 'bolters' of hybrid origin (from seed production), wild plants from populations close to carrot fields, and from populations far from fields. A total of 281 individuals were included in the study (Table 1).

Four carrot cultivars were chosen to represent the past and present cultivation history in the Lammefjord area: 'Fancy': an open-pollinated cultivar grown intensively and the major cultivar until ca. 1990; 'Bolero': a modern $\mathrm{F}_{1}$ cultivar grown as the predominant cultivar after 'Fancy', on ca. $80 \%$ of the cultivation area (1999); 'Carlo' and 'Maestro': late harvested $\mathrm{F}_{1}$ cultivars, each grown on about $5 \%$ of the area each (1999). From each of the cultivars, seedlings were germinated and leaf samples collected (sample sizes in Table 1).

Leaf samples of wild carrots were collected from three populations close to carrot fields in the Lammefjord region (Pop1-Pop3; see Table 1), and from four populations far from cultivation, but on the same island of Zealand (Bjerge, Præst $\varnothing$, Stigsnæs and Svin $\varnothing$, respectively; distances from fields in Table 1).

Leaf samples from bolting carrots (plants flowering within fields) were collected from five fields within the Lammefjord area. Only bolters with white roots, indicating that they were of cultivar $(q) \times$ wild hybrid origin (Wijnheijmer et al., 1989; Hauser and Bjørn, 2001) were included (orange-rooted bolters of cultivar origin are in this study represented by the cultivar plants). Three of these fields contained only few bolters that were therefore pooled into a synthetic population, Bolt1. The other two fields, both cultivated with 'Bolero', contained many bolting individuals (Bolt2 and Bolt3).

\section{AFLP analysis, genetic distances and population assignment}

Leaf samples were stored at $-80^{\circ} \mathrm{C}$ until DNA was extracted. Extraction and AFLP analysis were carried out as described in Shim and Jørgensen (2000). Four primer combinations were used E-CAC/M-AC, E-ACGG/ M-CTG, E-AGG/M-CTG and E-ACAG/M-CTG, and fragment bands were visualized on silver-stained gels.

Genetic distances between all individuals were estimated using a Euclidean genetic distance, required by the subsequent analysis of molecular variance (AMOVA; see below), and visualized by principal coordinate analysis using the statistics software Statistica 6.0.

Differentiation and affinities among populations and plant types (cultivars, bolters, wild-close and wild-far) were tested by reallocation of all individuals back to the full set of cultivars and populations. For this we used the software AFLPOP (version 1.1; Duchesne and Bernatchez, 2002; see below). 
Table 1 Samples of cultivars, bolters and wild carrots close to and far from fields used in the study

\begin{tabular}{|c|c|c|c|c|}
\hline Carrot type & $\begin{array}{l}\text { Variety/ } \\
\text { population }\end{array}$ & Characteristics & $\begin{array}{l}\text { Distance from } \\
\text { carrot fields }(\mathrm{km})\end{array}$ & Sample size \\
\hline \multicolumn{5}{|l|}{ Cultivars } \\
\hline & Fancy & Open-pollinated older cultivar & - & 13 \\
\hline & Bolero & $\mathrm{F}_{1}$ modern cultivar & - & 15 \\
\hline & Carlo & $\mathrm{F}_{1}$, recent & - & 15 \\
\hline & Maestro & $\mathrm{F}_{1}$, recent & - & 15 \\
\hline \multicolumn{5}{|l|}{ Bolters } \\
\hline & Bolt1 & Bolters pooled from three relatively clean Bolero fields ca. $2 \mathrm{~km}$ apart & Within & 17 \\
\hline & Bolt2 & From field with very many bolters & Within & 30 \\
\hline & Bolt3 & From field with very many bolters close to Pop 1 & Within & 24 \\
\hline \multicolumn{5}{|c|}{ Wild close to fields } \\
\hline & Pop1 & Road side neighbouring Bolt3 & 0.05 & 24 \\
\hline & Pop2 & Abandoned field close to one of the three populations pooled into Bolt1 & 0.35 & 24 \\
\hline & Pop3 & Roadside & 0.50 & 24 \\
\hline \multicolumn{5}{|c|}{ Wild far from fields } \\
\hline & Bjerge & Roadside & 14 & 20 \\
\hline & Præst $\varnothing$ & Roadside & 80 & 20 \\
\hline & Stigsnæs & Along the coast & 63 & 20 \\
\hline & Svin $\varnothing$ & At a small harbor & 71 & 20 \\
\hline
\end{tabular}

\section{Detection of hybrids}

To detect hybrids between cultivated, bolting, and wild individuals, we used two approaches: detection based on band frequencies in hypothetical hybrid classes and detection based on linkage disequilibrium. For the first approach, we used the software AFLPOP (version 1.1; Duchesne and Bernatchez, 2002). Individuals are here assigned to potential source populations based on the likelihood of observing their AFLP genotype in the source populations, given the population frequencies of AFLP bands. Additionally, individuals can be assigned to potential (synthetic) hybrid populations of different genealogy $\left(\mathrm{F}_{1}, \mathrm{~F}_{2}\right.$, and first backcrosses to each parental population), based on estimation of allele frequencies in the parental populations by assuming Hardy-Weinberg $(\mathrm{H}-\mathrm{W})$ equilibrium.

Before our analyses, data were pruned for redundant loci (bands) and bands with only small frequency differences between cultivars and populations (difference $<0.1$, if $0.2 \leqslant$ band frequency $\leqslant 0.8$; using options in AFLPOP).

To test whether wild populations close to fields contained hybrids with either cultivar or bolter parents (separate analyses), we assigned all individuals in each of the three wild-close populations to themselves, cultivars or bolters (pooled datasets containing all cultivar or bolting individuals) and to the four putative hybrid classes between them (using AFLPOP option 'Allocation (origin unknown)' with probabilities of population assignment calculated from 900 re-sampled individuals). Two criteria were used to detect hybrids: they should assign to a hybrid class with a likelihood 100 times higher than to the wild population from which it was sampled, and its probability of being wild should be significantly rejected while its probability of being a hybrid should not be rejected $(P<0.05$; that is, among 900 re-sampled 'individuals' of the wild population, 5\% score likelihoods less than or equal to the likelihood that the potential hybrid belongs to the population from which it was sampled). The hybrids thus detected were subsequently removed from their respective population source data files and the analysis repeated, this time with 1200 re-sampled individuals. For each of the detected hybrids, we also asked from which of the four cultivars and from which of the bolter populations came its most likely parent, by allocation of the hybrids to all populations of each. Additionally, we repeated the analysis using only Fancy (the open pollinated cultivar) among the cultivars or Bolt 2 and Bolt 3 among the bolters to minimize problems with departures from $\mathrm{H}-\mathrm{W}$ equilibrium (see Discussion).

With our second approach for detection of hybrids, we wanted to determine whether hybrids detected by the AFLPOP methods were likewise detected with a different method. The software NewHybrids (version 1.1 beta; Anderson and Thompson, 2002), assigns individuals to potential parental populations and hybrid classes using a Bayesian approach based on departures from $\mathrm{H}-\mathrm{W}$ and linkage disequilibrium. Individuals from the wild-close populations were allocated only to Fancy among the cultivars or Bolt2 and Bolt3 among the bolters to minimize problems with departures from $\mathrm{H}-\mathrm{W}$ and linkage equilibrium within the parental populations (see Discussion); these were also the most likely parental populations suggested by AFLPOP (see Results). The genotype data were reduced for redundancy and small frequency differences as above, and 3000 BurnIn's and 30.000 sweeps were used for the runs. Only individuals that were significantly different from the population from which they were sampled $(P<0.05)$ and not different from one of the hybrid classes $(P>0.05)$ were considered to be hybrids.

\section{Population differentiation with distance to fields}

We next asked whether wild plants growing close to carrot fields were on average more similar to cultivars than wild plants growing far from fields. Genetic 
distances (PhiPT) between the three groups were tested by Analysis of Molecular Variance (AMOVA) with the software GenAlEx (Peakall and Smouse, 2001), using 999 re-sampled individuals. We also tested if pairwise genetic distances between cultivated and wild individuals increased with geographic distance (that is, the distance from fields to wild populations (Table 1)), either by simple linear regression of Euclidean genetic distances (using Statistica 6.0), or by regression of kinship and relationship coefficients (estimators of the probability of identity of alleles for homologous genes, and of the proportion of genes identical to those in another individual, respectively, Hardy, 2003), using the software SPAGeDi (Hardy and Vekemans, 2002). For estimation of kinship and relationship coefficient we assumed no inbreeding; test statistics were calculated by permuting the spatial groups 1000 times. The four hybrids detected by allocation (see above and in Results) were excluded from the AMOVA and spatial analyses.

\section{Results}

The four AFLP primer combinations yielded a total of 78 clear, polymorphic bands; twelve of these were removed before our analyses as they were redundant or too similar in frequencies across our populations.

\section{Population differentiation}

Principal coordinate analysis of genetic distances between individuals (Figure 1) showed that cultivated and wild plants were well separated in general, that cv. Fancy was more similar to wild plants and bolters than the other three cultivars, that bolters were intermediate between cultivar and wild plants, and that wild plants close to fields were more similar to cultivars and bolters than were those far from fields.

These results were corroborated by the reassignment of individuals to cultivars and populations: forty-nine percent of the individuals reassigned to their own populations (using AFLPOP), on the condition that there should be more than a twofold difference in loglikelihood between the most and next-most likely populations (that is, a 100-fold difference in probability of assignment; Table 2). Four percent assigned to another population than their own; the majority of these were white-rooted bolters that assigned to another bolter population, and wild individuals close to fields that assigned to bolters or the reverse (Table 2). The remaining individuals did not assign (47\%; that is, they were similar to more than one population). When individuals were assigned simply to the population with the highest log-likelihood (difference $>0$ ), 75\% assigned to their own populations, and $25 \%$ assigned to another population or cultivar. Of these, $13 \%$ assigned to a different plant type (Table 2): there was a tendency for cultivars and bolters to be mis-assigned to each other, for wild individuals close to fields to assign to bolters and populations far from fields, and for individuals far from fields to assign to populations close to fields.

Bolters were more closely related to the cultivar Fancy than to any of the other cultivars. On average, $86 \%$ of the bolters assigned to Fancy if forced only to assign to cultivars (results not shown). This is also indicated by Figure 1. The three populations of bolters did not differ

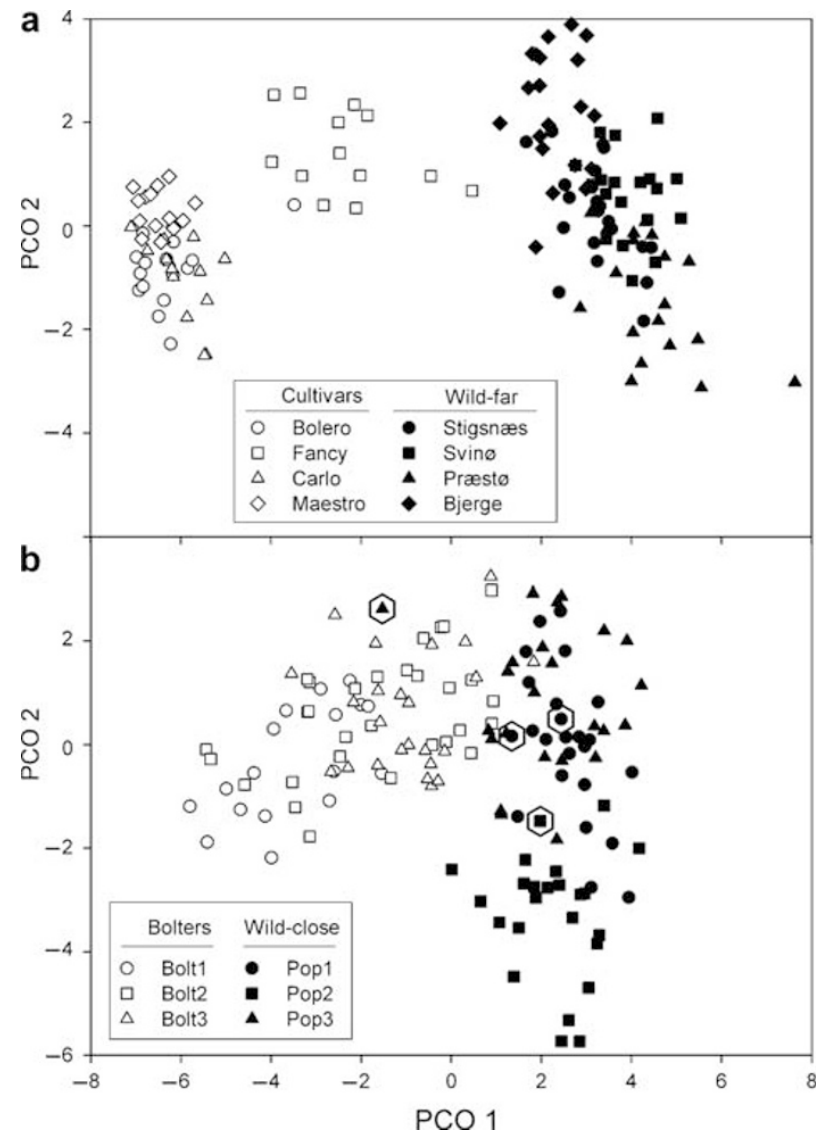

Figure 1 Principal coordinate analysis of pairwise genetic distances between individuals, for clarity divided into two panels: (a) cultivar plants and wild plants far from cultivated fields, and (b) bolters and wild plants close to fields. Individuals determined to be hybrids are indicated by hexagons.

in the frequencies with which they assigned to the four cultivars.

\section{Hybrids detected}

Four individuals from the wild-close populations were determined to be hybrids (using AFLPOP; Table 3, Figure 2); $5.6 \%$ of the sampled plants. One of the plants (3-24 in Table 3) could have been a 'bolter,' that is, originating from a seed spread from a white-rooted bolter into the natural population. However, the likelihood for this was only marginally higher than for being an $F_{1}$ or backcross plant (Figure 2). Three additional individuals fulfilled only one of the criteria for being a hybrid (see Methods).

None of the hybrids assigned to a specific genealogical class of hybrids with a higher likelihood (log-likelihood difference $>2$ ) than to other hybrid classes; in no case did the hybrids assign to the $\mathrm{F}_{1}$ class with the highest probability. All the hybrids assigned with higher probability to the white-rooted bolters than to cultivar plants (Figure 2). Among the bolters, they assigned only to Bolt2 and Bolt3 (log-likelihood difference $>2$; Table 3), and among the cultivars only to Fancy.

Three of the hybrids detected by AFLPOP were also determined to be hybrids by NewHybrids (3-19 were not detected by this method). They were all assigned to the 
Table 2 Reallocation of all individuals back to cultivars, bolters and wild populations close to carrot fields and far from fields

\begin{tabular}{|c|c|c|c|c|c|c|c|c|c|c|c|c|c|c|}
\hline \multirow[t]{3}{*}{ Allocated to } & \multicolumn{14}{|c|}{ Number of individuals among } \\
\hline & \multicolumn{4}{|c|}{ Cultivar } & \multicolumn{3}{|c|}{ Bolters } & \multicolumn{3}{|c|}{ Wild-close } & \multicolumn{4}{|c|}{ Wild-far } \\
\hline & Fancy & Bolero & Carlo & Maestro & Bolt1 & Bolt2 & Bolt3 & Pop1 & Pop2 & Pop3 & Bjerge & Præstø & Stigsnæs & Svin $\varnothing$ \\
\hline Fancy & $6(8)$ & & & & & (1) & & & & & & & & \\
\hline Bolero & & 9 (13) & (2) & & (1) & & & & & & & & & \\
\hline Carlo & & (1) & $12(13)$ & & (1) & (1) & & & & & & & & \\
\hline Maestro & & & & 15 & & & & & & & & & & \\
\hline Bolt1 & & (1) & & & $3(9)$ & $1(5)$ & $1(3)$ & & & & & & & \\
\hline Bolt2 & (5) & & & & $1(6)$ & $5(16)$ & (7) & (1) & & 1 & & & (1) & \\
\hline Bolt3 & & & & & & $4(7)$ & 7 (13) & (1) & (1) & & & & (1) & \\
\hline Pop1 & & & & & & & & $7(20)$ & & (1) & $1(2)$ & (2) & & (1) \\
\hline Pop2 & & & & & & & & & $15(20)$ & & & (1) & & \\
\hline Pop3 & & & & & & & $1(1)$ & (2) & & $11(20)$ & (2) & & & \\
\hline Bjerge & & & & & & & & & & (1) & $13(16)$ & & (2) & \\
\hline Præst $\varnothing$ & & & & & & & & & (1) & (1) & & $9(15)$ & (2) & \\
\hline Stigsnæs & & & & & & & & & (1) & & & (2) & $9(14)$ & (1) \\
\hline Svin $\varnothing$ & & & & & & & & & 1 & & & & & $16(18)$ \\
\hline None & 7 & 6 & 3 & & 13 & 20 & 15 & 17 & 8 & 12 & 6 & 11 & 11 & 4 \\
\hline
\end{tabular}

The first number in the cells shows the number of individuals that allocate to the given group with a likelihood 100 times larger than to any other group, the number in parenthesis shows the number that allocate to that group with the highest likelihood.

Table 3 Hybrids identified when assigning wild carrots collected close to fields to (a) cultivars, wild plants, and first and second generation hybrids between them, or (b) bolters, wild plants, and hybrids between them

\begin{tabular}{|c|c|c|c|c|c|c|c|c|c|c|}
\hline \multirow[t]{2}{*}{ Individual } & \multicolumn{5}{|c|}{ (a) assignment to cultivars, wild and hybrids } & \multicolumn{5}{|c|}{ (b) assignment to bolters, wild and hybrids } \\
\hline & $\begin{array}{l}\text { Most likely } \\
\text { genealogy }\end{array}$ & $\begin{array}{l}\text { Probability } \\
\text { of this } \\
\text { genealogy }\end{array}$ & $\begin{array}{l}\text { Likelihood } \\
\text { difference to } \\
\text { being wild }\end{array}$ & $\begin{array}{l}\text { Probability } \\
\text { of being } \\
\text { wild }\end{array}$ & $\begin{array}{l}\text { Most } \\
\text { likely } \\
\text { cultivar }\end{array}$ & $\begin{array}{l}\text { Most } \\
\text { likely } \\
\text { genealogy }\end{array}$ & $\begin{array}{l}\text { Probability } \\
\text { of this } \\
\text { genealogy }\end{array}$ & $\begin{array}{l}\text { Likelihood } \\
\text { difference to } \\
\text { being wild }\end{array}$ & $\begin{array}{l}\text { Probability } \\
\text { of being } \\
\text { wild }\end{array}$ & $\begin{array}{l}\text { Most likely } \\
\text { bolter pop. }\end{array}$ \\
\hline Pop1-5 & $\mathrm{F}_{1} \mathrm{~B}_{\mathrm{w}}$ & 0.059 & 2.9 & 0.000 & Fan & $F_{2}$ & 0.255 & 3.6 & 0.000 & Bolt2 \\
\hline Pop2-19 & $\mathrm{F}_{2}$ & 0.007 & 0.7 & 0.000 & Fan & $\mathrm{F}_{2}$ & 0.293 & 3.4 & 0.000 & Bolt3 \\
\hline Pop3-19 & $\mathrm{F}_{1} \mathrm{~B}_{\mathrm{w}}$ & 0.003 & 0.0 & 0.000 & Fan & $F_{2}$ & 0.102 & 2.0 & 0.000 & Bolt3 \\
\hline Рор3-24 & $\mathrm{F}_{2}$ & 0.190 & 9.2 & 0.000 & Fan & Bolter & 0.590 & 12.5 & 0.000 & Bolt2 \\
\hline
\end{tabular}

${ }^{a}$ Potential genealogical classes: wild, cultivars/bolters, $\mathrm{F}_{1}, \mathrm{~F}_{2}, \mathrm{~F}_{1} \mathrm{~B}_{\mathrm{w}}$ : first backcross to wild, $\mathrm{F}_{1} \mathrm{~B}_{\mathrm{c}}$ : first backcross to cultivars.

For each individual the following is shown: most likely genealogy, the probability of belonging to this genealogical class, the difference in assignment likelihood between this genealogy and the wild population from which it was collected, the probabilities of belonging to the wild population, and the most likely cultivar/bolter population. All tests were made using AFLPOP, significant test statistics are shown in bold; see Materials and methods for more detail.

same genealogical class as suggested by AFLPOP, except Pop 3-24 that was most likely to be a bolter $\times F_{1}$ plant or $\mathrm{F}_{2}$ (results not shown).

\section{Population differentiation with distance to fields}

Wild carrot populations close to fields were, as a group, more similar to cultivars than were wild populations far from fields (Figure 1), and had significantly lower pairwise genetic distances to the cultivars (Table 4). Genetic distances between cultivar and wild plants increased with geographic distance (slope $=0.03$; $P<0.05, R^{2}=0.06$ ), and kinship and relationship coefficients decreased (coefficients $=-0.00097$ and -0.00194 , respectively, $P=0.02$ (by resampling) and $R^{2}=0.14$ for both). The proportions of variance explained by these tests were low, however.

\section{Discussion}

Our study shows that adult plants derived from hybridization between cultivated and wild carrots can be found in wild populations growing in proximity to carrot fields in Denmark. This implies that pollen and seeds can flow from carrot fields into wild populations, and that the resulting hybrids survive under natural conditions. The hybrids we detected were most likely second generation hybrids $\left(\mathrm{F}_{2}\right.$ or backcross plants with wild parents), which originated from pollen or seeds dispersed from white-rooted bolters into the natural habitat. One individual could originate directly from a seed dispersed from white-rooted bolters. Alternatively, the hybrids could originate from even more advanced intercrosses $\left(B_{n}\right.$ and $\left.F_{n}\right)$, as our allocation method did not include such classes. If the hybrids we detected were indeed second generation hybrids, one of their parents must have survived and reproduced in the natural habitat.

Our results further suggest that continued hybridization and introgression has made wild populations close to carrot fields genetically more similar to cultivars than are wild populations further away from carrot fields (these results were significant, but only a low proportion of variance was explained by the contrast). Continued hybridization and interbreeding with hybrids seems to have led to introgression of, at least, neutral genes from cultivars into the wild populations. This again implies 

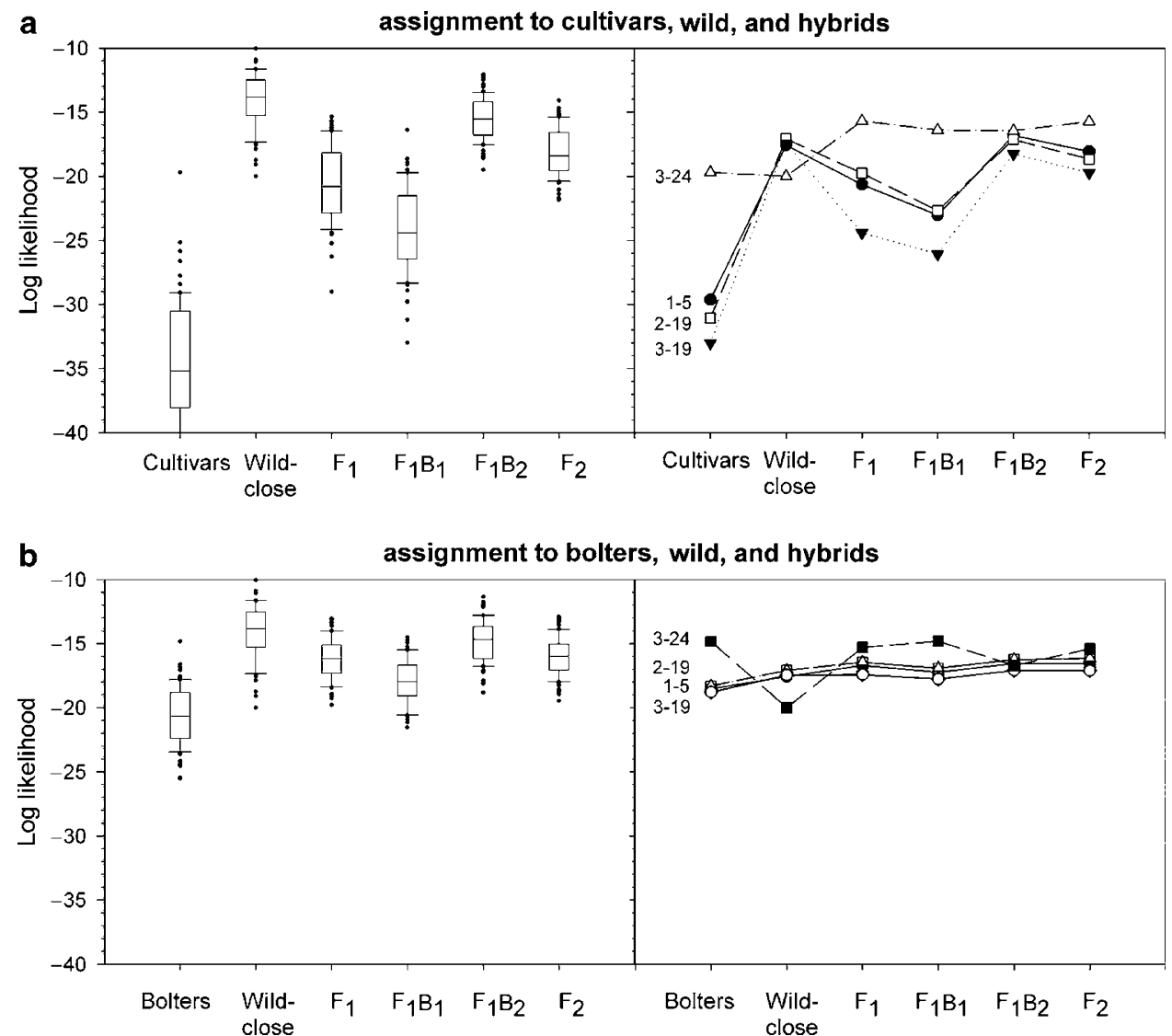

Figure 2 Assignment of wild carrots close to fields to (a) cultivars, wild carrots and first and second generation hybrids between them, or (b) bolters, wild plants and hybrids between them. In the left panels are shown the likelihood distributions for all the wild plants when assigned to the different classes on the first axes (box plots showing lower outliers, 10, 25, 50, 75, 90 percentiles and upper outliers), and in the right panels the assignment likelihoods of the four individuals determined to be hybrids (identities of individuals as in Table 3). Higher likelihood values indicate a higher similarity to the given class.

Table 4 Test of genetic differentiation between cultivars and wild populations close to and far from fields, using AMOVA

\begin{tabular}{lccc}
\hline & Cultivars & Wild-close & Wild-far \\
\hline Cultivars & & 0.356 & 0.445 \\
Wild-close & 0.001 & 0.001 & 0.053 \\
Wild-far & 0.001 & & \\
\hline
\end{tabular}

Abbreviation: AMOVA, analysis of molecular variance.

Genetic distances are shown above the diagonal, and their probabilities below.

that several generations of hybrids have been able to survive and reproduce in the natural populations. These results were obtained using data sets where all the early generation hybrids detected $\left(\mathrm{F}_{1}\right.$ and second-generation hybrids; including those that fulfilled only one of the criteria for assigning a hybrid) had been omitted; only individuals of a more advanced hybrid genealogy would thus contribute to these results. Carrots have been cultivated extensively in the Lammefjord for less than 100 years. Flow of cultivar genes into wild carrot populations thus seems to have influenced wild populations on a relatively short period of coexistence.

These results are consistent with other studies showing that hybrids between cultivated and wild carrots are able to survive and reproduce in natural habitats.
Wijnheijmer et al. (1989) found individuals with a morphology intermediate between wild and cultivated plants, suggesting that they were hybrids, growing close to a carrot seed production field in the Netherlands. Shim and Hauser (unpublished; also see Hauser et al., 2004) concluded that $F_{1}$ hybrids between cultivated and wild Danish carrots survive and flower as frequently, or almost as frequently, as wild carrots in open Danish grasslands. Umehara et al. (2005) crossed cultivated and wild Japanese carrots and found them $\left(\mathrm{F}_{1}\right)$ to be vigorous; however, it is not clear under what conditions the hybrids were tested. These studies, together with our own, suggest that hybrids of both the $F_{1}$ and also more advanced genealogies are relatively fit in natural habitats.

In contrast to this, Hauser (2002) found that $F_{1}$ hybrids were more easily killed by frost than wild plants (in climate chambers). Also, Small (1984) and Bradeen et al. (2002) argued against extensive gene transfer between cultivated and wild carrots, based on their results that wild and cultivated carrots form separate morphological and genetic groups, respectively (the principal component and cluster analyses of Bradeen et al. (2002) actually do show an overlap between cultivated and wild accessions, which somewhat contradict their conclusion). However, neither of the two latter studies addressed hybridization directly. It is not clear from Small (1984) 
and Bradeen et al. (2002) if they included wild populations close to potential sources of cultivar pollen, and it is questionable whether their methods would have been able to determine gene flow at a relatively low level between wild carrots and cultivars. Human selection against wild traits in breeding and cultivation, and natural selection against some or many cultivar traits in wild habitats, may keep the two types distinct at an overall level, as suggested by these authors and by our own results on genetic differentiation between cultivated and wild carrots. Other traits and markers may still interchange locally and perhaps spread gradually among a wider set of populations, as suggested by our results. Similar results have been found in sunflower (Whitton et al., 1997) and radish (Snow et al., 2001).

The hybrids we detected in populations close to fields were most likely produced by white-rooted bolters (in contrast to cultivars), and among these, by populations Bolt2 and Bolt3. These were collected from fields that were heavily infested with weedy, white-rooted bolters. Because of lack of weeding in these fields at some time in the past, a large seed bank and weed population had built up. White-rooted bolters were shown by Hauser and Bjørn (2001) to be hybrids (cultivated $q \times$ wild) produced by pollination of cultivar seed plants by pollen from surrounding wild plants; this takes place in regions warmer than Denmark. Genetically, white-rooted bolters should therefore be intermediate between cultivar and wild plants from the seed production areas, as has been shown for bolting weed beets (Van Dijk, 2004). Our study did not include such wild plants, but nevertheless shows that white-rooted bolters are genetically intermediate between cultivar and wild Danish plants (Figure 1 and Table 2). None of the hybrids assigned to Bolt1, which was collected in clean fields containing only few whiterooted bolters. This suggests that the rare fields with heavy infestation of bolters produce a large share of the hybrids in wild populations surrounding carrot fields. However, given the large number of carrot fields in the Lammefjord area, and that even 'clean' well-kept fields almost always contain some white-rooted bolters, the total population size of flowering bolter individuals in the region is large, and probably of the same or greater magnitude than the surrounding populations of wild carrots with which they share pollinators (Hauser and Bjørn, 2001).

White-rooted bolters were more similar to Fancy than to any of the other cultivars. Fancy was the predominant cultivar in the Lammefjord from ca. 1980-1990, and our results suggest that we still see its genetic influence on the populations of bolters. Many of these grew outside the sowing rows, especially in Bolt2 and Bolt3, and in patches in the fields (Hauser and Bjørn, 2001), showing that they germinated from the seed bank and not from sowed seeds. They therefore originate from an earlier generation of bolters in the field, and as a 4-year rotation is normally used by carrot farmers in the Lammefjord, only one or two generations of bolters separate the present day bolters from when Fancy was still predominant. A recent study in oilseed rape (Brassica napus) also shows that volunteers, which germinate from the seed bank of past cultivation, can be old and originate from several rotations back in time (Jørgensen et al., 2007).

In our study, we detected hybrids by allocation methods that assume $\mathrm{H}-\mathrm{W}$ and linkage equilibrium.
Our findings that the most likely parents of the hybrids were white-rooted bolters from Bolt 2 and Bolt3, and that these were probably derived from Fancy, show that our results are robust to these assumptions. Fancy seeds are produced by open pollination, and since carrots are insect pollinated and mostly outcrossed (Thompson, 1962), genotype frequencies are expected to be in H-W proportions. Most of the bolters in Bolt2 and Bolt3 originated from open pollinations among bolters in at least one previous generation, which would again lead to $\mathrm{H}-\mathrm{W}$ and (close to) linkage equilibrium.

\section{Perspectives}

Most studies of hybridization between cultivated and wild plants have focused on the direct transfer of pollen from cultivars to related weedy and wild plants. Our results show that this view may be too narrow. Cultivar genes are likely to move into wild Danish populations from white-rooted hybrid bolters, which originate from seed production fields elsewhere in the world. Largescale transportation of seeds may thus create a gene flow between wild populations and cultivars in very different parts of the world. This dynamic has so far only been described in carrots and in cultivated and wild beets (Arnaud et al., 2003; Van Dijk, 2004). In beets, this has created serious problems with weedy beets in northern Europe, supporting the idea that hybridization between cultivated and wild plants may lead to increased weediness (Ellstrand and Schierenbeck, 2000; Campbell et al., 2006). A similar argument may hold for carrots: wild carrot is a serious weed in North America (for example, Mitich, 1996), and a recent publication (Umehara et al., 2005) shows that it is spreading rapidly in Japan after recent introduction. In contrast, wild carrots are not usually considered weedy in Europe. Our studies suggest that the 'wild' plants that have colonized new continents and regions in recent times could have been derived from hybrids imported with cultivar seeds many more of these would have reached new continents and regions than seeds of pure wild plants. Repeated introductions through seed trade are in general responsible for a large share of invasive species in, for example, North America (Mack and Erneberg, 2002).

Our results also suggest that volunteers (self-set plants from a previous year's crop) germinating from the seed bank may play a significant role in the hybridization between cultivated and wild plants by increasing exposure and synchronization (Jørgensen et al., 2007). In other words, volunteers may act as 'bridge populations'. Seed dormancy allows a proportion of the seeds from the field to survive until the next crop in which they can grow; hybrids are at an advantage relative to crop seeds, as they often inherit a degree of dormancy from their wild parents.

\section{Acknowledgements}

Ole Mohr Madsen, Dæhnfeldt A/S, and Gert Lodberg, GF Garta, kindly provided seeds from cv Fancy and from cv Carlo, Maestro, and Bolero, respectively. Helle Hansen and Hanne Pedersen conducted the lab work, and Brita Dahl Jensen and Rikke B. Jørgensen inspired and discussed the project. This research was financed by the Danish Strategic Environmental Research Programme 
and the Centre for Bioethics and Risk Assessment, through a grant from the Danish Research Agency.

\section{References}

Anderson EC, Thompson EA (2002). A model-based method for identifying species hybrids using multilocus genetic data. Genetics 160: 1217-1229.

Arnaud JF, Viard F, Delescluse M, Cuguen J (2003). Evidence for gene flow via seed dispersal from crop to wild relatives in Beta vulgaris (Chenopodiaceae): consequences for the release of genetically modified crop species with weedy lineages. Proc $R$ Soc Lond B Biol Sci 270: 1565-1571.

Atherton JG, Craigon J, Basher EA (1990). Flowering and bolting in carrot. I. Juvenility, cardinal temperatures and thermal times for vernalization. J Hort Sci 65: 423-429.

Bradeen JM, Bach IC, Briard M, Le Clerc V, Grzebelus D, Senalik DA et al. (2002). Molecular diversity analysis of cultivated carrot (Daucus carota L.) and wild Daucus populations reveals a genetically nonstructured composition. J Am Soc Hortic Sci 127: 383-391.

Campbell LG, Snow AA, Ridley CE (2006). Weed evolution after crop gene introgression: greater survival and fecundity of hybrids in a new environment. Ecol Lett 9: 1198-1209.

D'Antuono LF (1985). Studio sull'inquinamento genetico causato da polline de tipi spontanei in carota da seme. Rivista Agronomia 19: 297-304.

Duchesne P, Bernatchez L (2002). AFLPOP: a computer programme for simulated and real population allocation based on AFLP data. Mol Ecol Notes 3: 380-383.

Ellstrand NC (2003). Dangerous Liaisons? When Cultivated Plants Mate with their Wild Relatives. The Johns Hopkins University Press: Baltimore.

Ellstrand NC, Schierenbeck KA (2000). Hybridization as a stimulus for the evolution of invasiveness in plants? Proc Natl Acad Sci USA 97: 7043-7050.

Gary NE, Witherell PC, Lorenzen K, Marston JM (1977). The interfield distribution of honey bees foraging on carrots, onions, and safflower. Environ Entomol 6: 637-640.

Hardy OJ (2003). Estimation of pairwise relatedness between individuals and characterisation of isolation by distance processes using dominant genetic markers. Mol Ecol 12: $1577-1588$.

Hardy OJ, Vekemans X (2002). SPAGeDi: a versatile computer program to analyse spatial genetic structure at the individual or population levels. Mol Ecol Notes 2: 618-620.

Harlan JR (1982). Relationships between weeds and crops. In: Holzner W, Numata N (eds). Biology and Ecology of Weeds. Dr W. Junk Publishers: Hague. pp 91-96.

Hauser TP (2002). Frost sensitivity of hybrids between wild and cultivated carrots. Conserv Genet 3: 75-78.

Hauser TP, Bjørn GK (2001). Hybrids between wild and cultivated carrots in Danish carrot fields. Genet Res Crop Evol 48: 499-506.

Hauser TP, Bjørn GK, Magnussen L, Shim SI (2004). Hybrids between cultivated and wild carrots: a life history. In: Den Nijs HCM, Bartsch D, Sweet J (eds). Introgression from Genetically Modified Plants into Wild Relatives. CABI Publishing: Wallingford. pp 41-51.

Hauser TP, Jørgensen RB, Østergård H (1998a). Fitness of backcross and $\mathrm{F}_{2}$ hybrids between weedy Brassica rapa and oilseed rape (B. napus). Heredity 81: 436-443.

Hauser TP, Shaw RG, Østergård H (1998b). Fitness of $F_{1}$ hybrids between weedy Brassica rapa and oilseed rape (B. napus). Heredity 81: 429-435.
Hegde SG, Nason JD, Clegg JM, Ellstrand NC (2006). The evolution of California's wild radish has resulted in the extinction of its progenitors. Evolution 60: 1187-1197.

Heywood VH (1983). Relationships and evolution in the Daucus carota complex. Israel J Bot 32: 51-65.

Hooftman DAP, Oostermeijer JGB, Jacobs MMJ, Den Nijs HCM (2005). Demographic vital rates determine the performance advantage of crop-wild hybrids in lettuce. J Appl Ecol 42: 1086-1095.

Jørgensen T, Hauser TP, Jørgensen RB (2007). Adventitious presence of other varieties in oilseed rape (Brassica napus) from seed banks and certified seed. Seed Sci Res (in press).

Lacey EP (1988). Latitudinal variation in reproductive timing of a short-lived monocarp, Daucus carota (Apiaceae). Ecology 69: 220-232.

Lexer C, Welch ME, Raymond O, Rieseberg LH (2003). The origin of ecological divergence in Helianthus paradoxus (Asteraceae): selection on transgressive characters in a novel hybrid habitat. Evolution 57: 1989-2000.

Lynch M (1991). The genetic interpretation of inbreeding depression and outbreeding depression. Evolution 45: 622-629.

Mack RN, Erneberg M (2002). The United States naturalized flora: largely the product of deliberate introductions. Ann Missouri Bot Garden 89: 176-189.

Mitich LW (1996). Wild carrot (Daucus carota L.). Weed Techn 10: 455-457.

Peakall R, Smouse PE (2001). GenAlEx V5: Genetic Analysis in Excel. Population genetic software for teaching and research Australian National University: Canberra, Australia.

Pylkov KV, Zhivotovsky LA, Christiansen FB (2000). The strength of the selection barrier between populations. Genet Res 76: 179-185.

Rhymer JM, Simberloff D (1996). Extinction by hybridization and introgression. Annu Rev Ecol Syst 27: 83-109.

Shim SI, Jørgensen RB (2000). Genetic structure in cultivated and wild carrots (Daucus carota L.) revealed by AFLP analysis. Theoret Appl Genet 101: 227-233.

Small E (1978). A numerical taxonomic analysis of the Daucus carota complex. Can J Bot 56: 248-276.

Small E (1984). Hybridization in the domesticated-weed-wild complex. In: Grant WF (ed). Plant Biosystematics. Academic Press: Toronto. pp 195-210.

Snow AA, Uthus KL, Culley TM (2001). Fitness of hybrids between weedy and cultivated radish: implications for weed evolution. Ecol Appl 11: 934-943.

Song ZP, Li B, Chen JK, Lu BR (2005). Genetic diversity and conservation of common wild rice (Oryza rufipogon) in China. Plant Species Biol 20: 83-92.

Thompson J (1962). Natural cross-pollination in carrots. Proc Am Soc Hort Sci 81: 332-334.

Umehara M, Eguchi I, Kaneko D, Ono M, Kamada H (2005). Evaluation of gene flow and its environmental effects in the field. Plant Biotechn 22: 497-504.

Van Dijk H (2004). Gene exchange between wild and crop in Beta vulgaris: how easy is hybridization and what will happen in later generations?. In: Den Nijs HCM, Bartsch D, Sweet J (eds). Introgression from Genetically Modified Plants into Wild Relatives. CABI Publishing: Wallingford. pp 41-51.

Whitton J, Wolf DE, Arias DM, Snow AA, Rieseberg LH (1997). The persistence of cultivar alleles in wild populations of sunflowers five generations after hybridization. Theor Appl Genet 95: 33-40.

Wijnheijmer EHM, Brandenburg WA, Ter Borg SJ (1989). Interactions between wild and cultivated carrots Daucus carota L. in the Netherlands. Euphytica 40: 147-154. 